\title{
Trypanosoma cruzi: Paninfectivity of CL Strain during Murine Acute Infection
}

\author{
Henrique L. Lenzi, ${ }^{*}, 1$ Denise N. Oliveira,* \\ Morgana T. Lima, $\dagger$ and Cerli R. Gattass $\neq$
}

*Department of Pathology, Institute Oswaldo Cruz, FIOCRUZ, Manguinhos, 21045-900, Rio de Janeiro, RJ, Brazil; $\dagger$ Department of Histology and Embryology, Institute of Biomedical Science, and $\$$ Institute of Biophysics Carlos Chagas Filho, Universidade Federal do Rio de Janeiro, Ilha do Fundão, 21949-900, Rio de Janeiro, RJ, Brazil

\begin{abstract}
Lenzi, H. L., Oliveira, D. N., Lima, M. T., And Gattass, C. R. 1996. Trypanosoma cruzi: Paninfectivity of CL strain during murine acute infection. Experimental Parasitology 84, 1627. A systematic study of the distribution of intracellular parasites in the organs and tissues of mice acutely infected (15 days) with the CL strain of Trypanosoma cruzi was performed. Almost all tissues and organs were parasitized with different intensities, including several epithelial cell types. In addition to striated, cardiac, and smooth muscles a very high parasitism of fat cells, pancreas, and genital adnexa was observed. A smaller number of parasites was found in all other structures studied except in highly vascularized structures such as in the penile corpora cavernosa, pulmonary and renal parenchyma, islets of Langerhans, hepatic sinusoids, and in atrial endothelium. This paper also shows, for the first time in the literature, the parasitism of milky spots, cornea epithelium, cornea stroma, retroorbital fibroblasts, seminal vesicles, and coagulative, Cowper's, urethral, preputial, sebaceous anal, and clitoris glands. The results indicated that CL strain is highly invasive, being able to infect cells derived from the three embryonic layers (ectoderm, mesoderm, and endoderm), suggesting that the paninfectivity may influence the outcome of immunological and pathological events. (c) 1996 Academic Press, Inc.

Index Descriptors And AbBReviations: Chagas' disease; Trypanosoma cruzi; protozoa; CL strain; infectivity; pathology; epithelial cells; adipose tissue; H\&E, hematoxylin-eosin.
\end{abstract}

\section{INTRODUCTION}

Trypanosoma cruzi is a very polymorphic parasite and differences in infectivity and biological characteristics among the strains have been described (Dvorak et al. 1988; McDaniel and Dvorak 1993). Although trypomastigotes from $T$. cruzi can invade and proliferate in most of the vertebrate cells tested in vitro, differences in tissue tropism for the various strains have been described in experimental models (Taliaferro and Pizzi 1955; Bice and Zeledon 1970; Shoemaker et al. 1970; Melo and Brener 1978). In spite of that, independent of the strain, the pathology of the chronic phase involves mainly the cardiac and skeletal

${ }^{1}$ To whom correspondence should be addressed. muscles and the gastrointestinal tract. Maybe for this reason, investigation of pathological aspects induced by $T$. cruzi infection in experimental models has been directed to these structures, underestimating the importance of other organs and tissues on the pathogenesis of the disease. Indeed, as pointed out by Chagas (1910) and others (Watkins 1966; Bice and Zeledon 1970), T. cruzi can invade several organs and tissues whose commitment may contribute to the establishment of the disease and resultant immunologic response, pathology, or mortality.

This paper utilizes mice acutely infected with the $T$. cruzi CL strain to investigate the involvement of organs, other than muscle cells, on the pathology of experimental Chagas' disease. The CL strain, isolated from naturally infected Triatoma infestans (Brener and 
Chiari 1963), is described as a myotropic strain, which preferentially infects heart and skeletal muscle (Melo and Brener 1978). Our results show that this strain is ubiquitously infective, inducing extensive alterations on the lymphohematopoietic system (manuscript in preparation) and in almost all cells and tissues of mice. In addition of showing new places of parasitization by $T$. cruzi, this paper focuses on the diverse tissues and anatomical structures specially ignored or not pointed out by most researchers on $T$. cruzi, which emphasize mainly the reticulo- and myotropism of this parasite (Andrade et al. 1970).

\section{Materials AND Methods}

The CL strain of $T$. cruzi, isolated from naturally infected $T$. infestans collected from a house in Rio Grande do Sul, Brasil (Brener and Chiari 1963), was maintained by passages through BALB/c mice, every 14 days. Infection with this strain was achieved by intraperitoneal injection of $0.2 \mathrm{ml}$ PBS-diluted blood containing $10^{5}$ trypomastigotes.

Either male or female 6-week-old BALB/c mice, from our own animal facilities, were used throughout the experiments. The mice were separated according to sex and housed in groups of five to six per cage.

Twelve BALB/c mice from both sexes, weighing around 16-20 g, were sacrificed on Day 15 after infection. Tissue samples were taken from the heart, lymph nodes, thymus, spleen, milky spots from thoracic, abdominal, and testicular cavities, salivary glands, lung, trachea, thyroid, liver, tongue, nasal mucosa, eye, diaphragm, kidney, ureter, adrenal glands, pancreas, mesentery, urinary bladder, penis, testis, epididymis, vas deferens, vesicular, coagulating Cowper's, and preputial glands, uterus, uterine tube, ovaries, skin, striated muscles, bones, bone marrow (from several places), teeth and tail, esophagus, stomach, intestine, and brain. The intestines were processed according to the Swiss roll technique (Lenzi and Lenzi 1986). Samples were fixed in Formalin-Millonig buffer (Carson et al. 1973) and embedded in paraffin. Sections were stained with hematoxylin-eosin (H\&E) and Lennert's Giemsa.

\section{RESUlTS}

Almost all tissues and organs were parasitized with different levels of intensity (Table I). In general, the numbers of parasites were higher in the brown and white adipose tissue, atrial cardiac muscle, striated muscle of differ- ent places, muscular layer of gastrointestinal tract, sebaceous anal glands (Fig. 1), pancreas, autonomic ganglions, wall of pulmonary and renal veins, and epididymis. The adipose tissue presented a universal panniculitis, with a large number of parasites, macrophages, lymphocytes, and necrotic cells (Fig. 3). Without involvement of epidermis, high numbers of parasites were found in the dermis of the skin close to the anus and external genitalia, including the prepuce. The parasites formed rows or small nests in the dermis without inflammatory infiltrate or caused only a little monocyte/macrophage reaction (Fig. 5). It was impossible by conventional microscopy to specify the type of cell or structure involved (fibroblasts, macrophages, dermal nerve cells ?). Similar aspects were seen in the corneal stroma (Figs. 9 and 10), and parasites were also localized in the retroorbital fibroblasts between choroid and extraocular muscle (Fig. 11). Parasites were also detected in the interstitium of lachrymal glands (Fig. 12). Pancreas showed a diffuse interstitial pancreatitis, with edema, monocyte/macrophage infiltration specially around intralobular ducts, occasional lobular atrophy, and plenty of parasites inside macrophages or/and myoepithelial cells, excluding acinar cells and islets of Langerhans. Similar aspects, but less intense, were observed in the interstitium of parotid, submaxillary, and major sublingual glands. In the endocrine glands, the parasite was found mainly in the zona fasciculata, less frequently in the zona glomerulosa of the adrenal gland, in isolated macrophages in the thyroid interstitium, and in follicular granulosa of ovary. Parasites were searched for, unsuccessfully, in adrenal medulla, islets of Langerhans, theca layer of ovary, and testicular Leydig cells.

Isolated or small nests of parasites were detected in epithelial layer of trachea (Fig. 6), urinary bladder (Fig. 7), renal pelvis (Fig. 8), mammary ducts, cornea, epididymis, and in pale-staining cells of anal sebaceous and preputial glands. Only one mouse presented isolated subcapsular macrophages filled up by $T$. cruzi amastigotes in the liver. In general, in 
TABLE I

Sites Where Trypanosoma cruzi Were Located after 15 Days of Infection by CL Strain

\begin{tabular}{|c|c|c|c|}
\hline LOCATION & INTENSITY & LOCATION & \begin{tabular}{|l|} 
INTENSITY \\
\end{tabular} \\
\hline BLOOD VESSELS & & FEMALE REPRODUCTIVE SYSTEM & \\
\hline Pulmonary Veins & + & Vagina & + \\
\hline Aorta (Adventitia) & + & Uterus & $+1-$ \\
\hline Jugular Vein & + & Oviduct & + \\
\hline \multirow[t]{2}{*}{ Renal Veins } & + & Ovary (granulosa cells) & + \\
\hline & & Mesovary & + \\
\hline \multicolumn{2}{|l|}{\begin{tabular}{|l|} 
RESPIRATORY SYSTEM \\
\end{tabular}} & Clitoris Glands & + \\
\hline Lung & $+1-$ & Mammary Glands & + \\
\hline \multirow[t]{2}{*}{ Trachea } & + & & \\
\hline & & MALE REPRODUCTIVE SYSTEM & \\
\hline \multicolumn{2}{|l|}{ GASTROINTESTINAL TRACT } & Preputial Glands & + \\
\hline Tongue & + & Penis & + \\
\hline Esophagus & + & Testis - Seminiferous Tubules & - \\
\hline Stomach & + & Testis - Albuginea & + \\
\hline Small Intestine & ++ & Epididymis & ++ \\
\hline \multirow[t]{2}{*}{ Large Intestine } & ++ & Vas Deferens & + \\
\hline & & Seminal Vesicles & + \\
\hline \multirow[t]{2}{*}{ MESENTERIUM } & ++ & Coagulative Glands & + \\
\hline & & Ampullary Glands & - \\
\hline \multicolumn{2}{|l|}{ NERVOUS SYSTEM } & Bulbo Urethral Glands & + \\
\hline Central & - & Urethral Glands & + \\
\hline Peripheral & + & Prostate & + \\
\hline Autonomic Ganglia & + & & \\
\hline \multirow[t]{2}{*}{ Auerbach Plexus } & + & KIDNEY & \\
\hline & & Capsule & + \\
\hline \multicolumn{2}{|l|}{ EXOCRINE GLANDS } & Parenchyma (close to Pelvis) & $+/-$ \\
\hline Parotid Glands & $+H$ & & \\
\hline Submaxillary Glands & + & URINARY TRACT & \\
\hline Sublingual Glands & + & Renal Pelvis & + \\
\hline Serous/Mucous Intralingual Glands & - & Ureter & $+1-$ \\
\hline Exocrine Pancreas & ++ & Urinary Bladder & + \\
\hline Dermal Sebaceous Glands & + & Urethra & + \\
\hline Anal Sebaceous Glands & + & & \\
\hline \multirow[t]{2}{*}{ Lachrymal Glands } & + & \begin{tabular}{|l} 
ADIPOSE TISSUE \\
\end{tabular} & \\
\hline & & Brown & $+H$ \\
\hline \multicolumn{2}{|l|}{ ENDOCRINE GLANDS } & Univacuolar & +++ \\
\hline Thyroid & + & & \\
\hline Adrenals & + & EYE & \\
\hline Endocrine Pancreas & - & Corneal Epithelium & + \\
\hline \multirow[t]{2}{*}{ Leydig Cells } & - & Corneal Stroma & + \\
\hline & & Retroorbital Fibroblasts & + \\
\hline \multicolumn{4}{|l|}{ LYMPHOHEMATOPOIETIC ORGANS } \\
\hline Thymus & + & LIVER & $+/-$ \\
\hline Bone Marrow & $+/-$ & & \\
\hline Lymph Nodes & + & GALLBLADDER & N.E. \\
\hline Spleen & + & & \\
\hline Milky Spots & + & \begin{tabular}{|l|} 
SKIN \\
\end{tabular} & ++ \\
\hline EPIPLOON & + & CARTILAGE & - \\
\hline
\end{tabular}

Note. $+/-$ to ++++ indicates levels of parasitism intensity and N.E. indicates not examined.

this organ, there were small aggregates of macrophages with few or no parasites inside. In the lymphohematopoietic organs, nests of parasites were observed in practically all animals in macrophages of the thymus, lymph nodes (neck, renal hilus, justa-thymus, and justa-pancreas), spleenic red pulp, peritoneal milky spots (Figs. 15 and 16), and rarely in bone marrow macrophages. In these omental structures and in mesenteric membranes the 

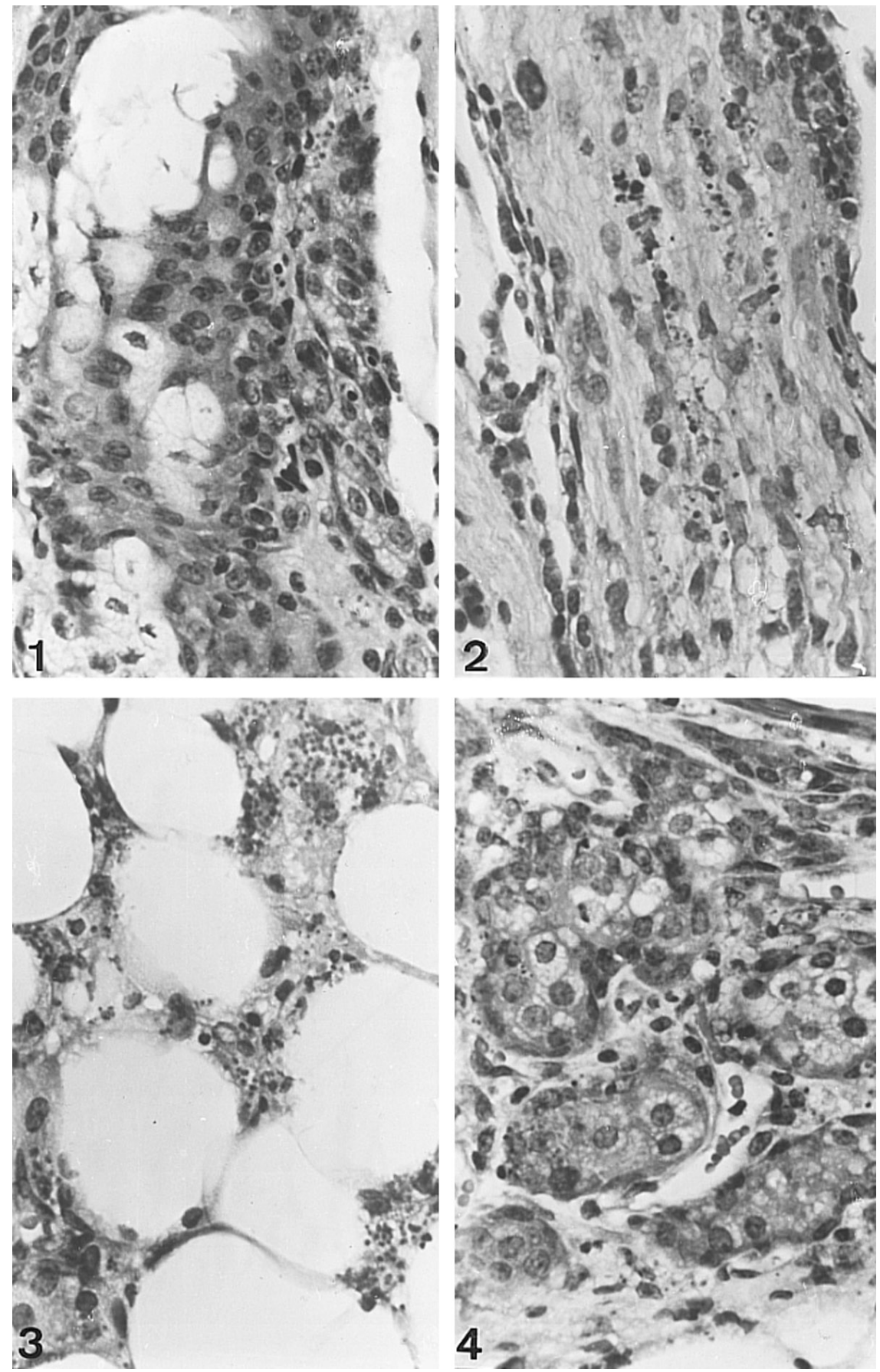

FIG. 1. Nests of T. cruzi in the interstitium of sebaceous anal gland. H\&E. $\times 500$. Fig. 2. Peripheral nerve in mesenterium with several $T$. cruzi nests in Schwann cells. H\&E. $\times 500$. FIG. 3. Univacuolated adipose tissue showing numerous and large $T$. cruzi nests. H\&E. $\times 500$. FIG. 4. T. cruzi nests in interstitium and in sebaceous cell of preputial gland. H\&E. $\times 500$. 

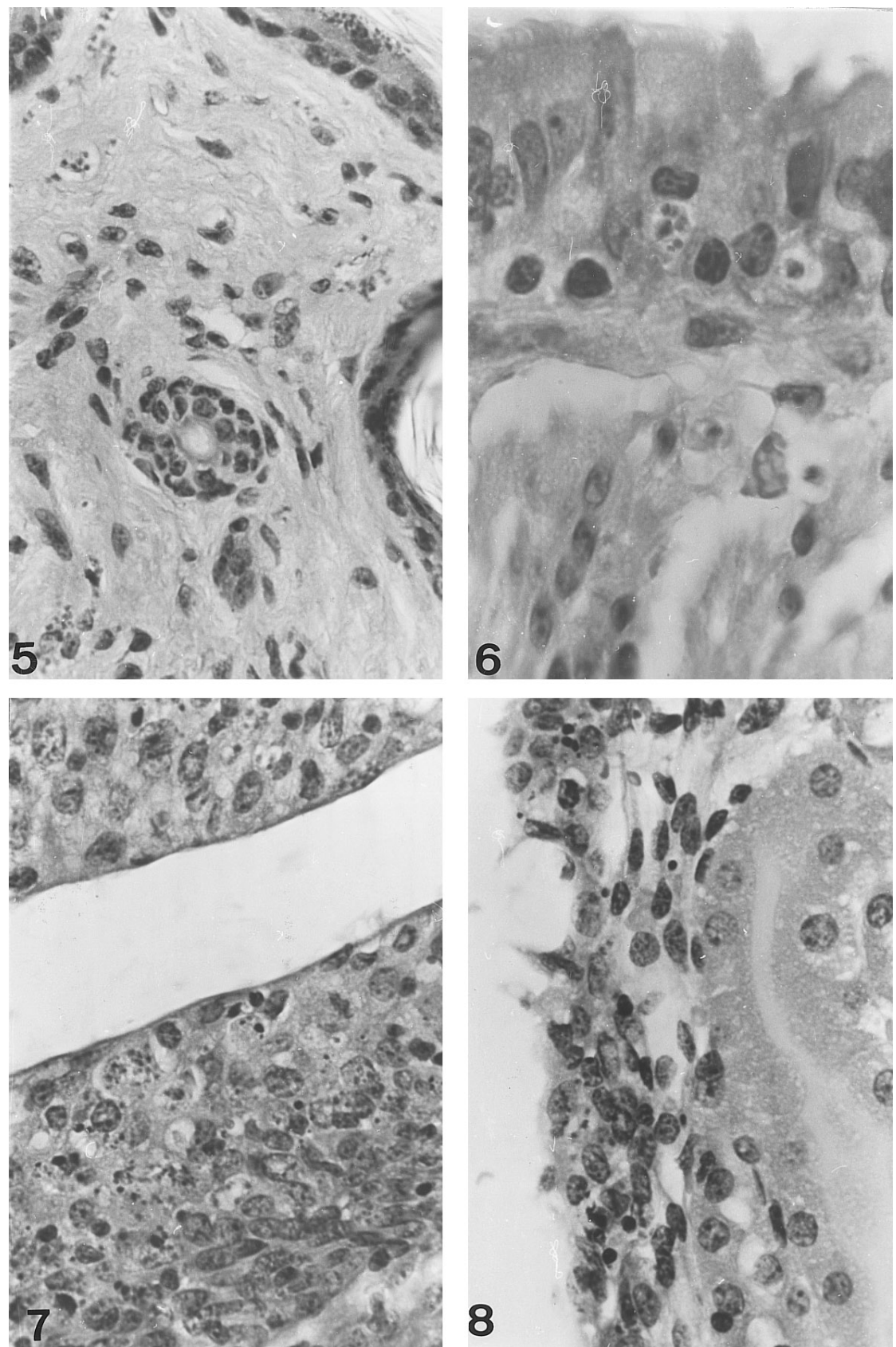

FIG. 5. T. cruzi nests and rows in the dermis, without inflammatory reaction. H\&E. $\times 500$. FIG. $6 . T$. cruzi nests in tracheal epithelial cells. H\&E. $\times 1250$. FIG. 7. Large numbers of $T$. cruzi nests in urothelial cells of the urinary bladder, some of them located very close to the lumen. H\&E. $\times 500$. FIG. 8. T. cruzi nests in epithelial cells of the renal pelvis, close to a proximal tube. H\&E. $\times 640$. 

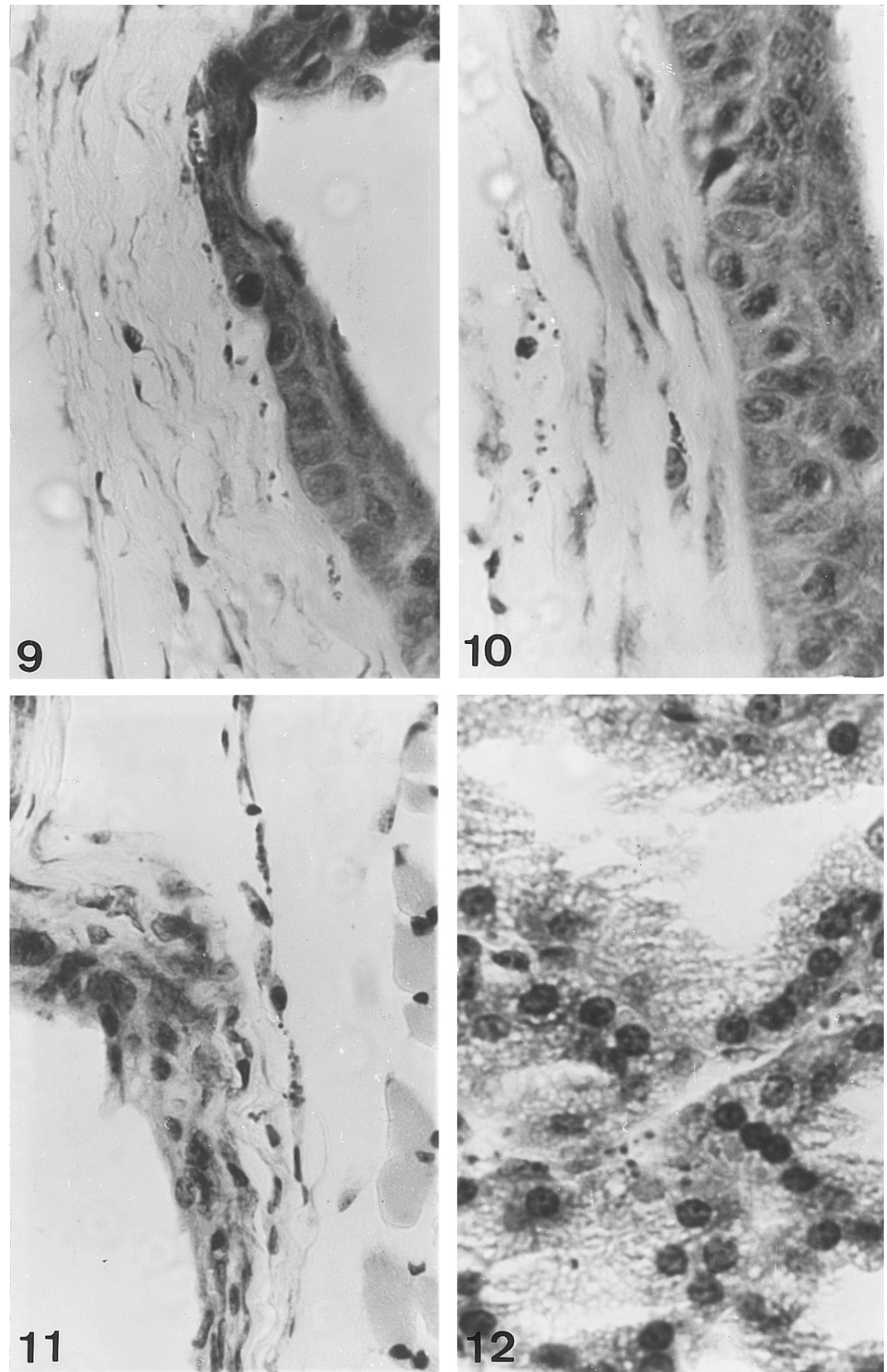

FIG. 9. Intraepithelial nest and rows of $T$. cruzi in the stroma of the cornea. Lennert's Giemsa. $\times 640$. FIG. 10. Rows of $T$. cruzi in corneal stroma. Lennert's Giemsa. $\times 800$. FIG. 11. T. cruzi nests in retroorbital fibroblasts, between choroid and extraocular muscle. H\&E. $\times 640$. FIG. 12. Small T. cruzi nests in the interstitium of lachrimal gland. H\&E. $\times 800$. 
parasites were also found inside mesothelial cells (Figs. 13-16). The thymus exhibited severe cortical atrophy with thymocyte apoptosis. Parasites were not detected in brain. However, they were often present in peripheral nerves (Fig. 2), Auerbach plexus (Schwann cells), and in the interstitium of sympathetic and parasympathetic ganglia.

Both male and female reproductive systems were intensively involved by parasites, which were detected in the mesovarium; ovarian follicular granulosa; lamina propria and muscular coat of the oviduct; muscular and adventitia of the uterus; lamina propria, muscular coat and adventitia of the vagina; epithelium of excretory ducts and periductal adipose cells of mammary glands; and in periductal and interstitial fibroblasts of clitoris glands. In the male reproductive system, large numbers of parasites were detected in the interstitial tissue and epithelial cells of epididymis; lamina propria and muscular layer of prostate, seminal vesicles, coagulative glands, and vas deferens; interstitium and sebaceous cells of preputial glands (Fig. 4); interstitium and vacuolated epithelial cells of Cowper's glands; interstitium of urethral glands; connective tissue under the penile urethra and in the penile tunica albuginea surrounding the corpora cavernosa; in the dermis of the prepuce and in the testicular albuginea. In one ampullary gland analyzed, parasites were not identified. In the male reproductive system the parasites predominated in the epididymis and preputial glands.

\section{DisCUSSION}

Except in the opossum (Deane et al. 1984; Lenzi et al. 1984), T. cruzi is an obligate intracellular parasite. It is well established that, both in vitro and in vivo, T. cruzi can infect a great variety of cells types including fibroblasts, epithelial and endothelial cells, myocytes, and macrophages. Trypanosomes were also found in the cephalic end of a spermatozoon (Vianna 1911). The mechanisms by which $T$. cruzi invades cells is not completely understood and recently Ming et al. (1995) proposed that $T$. cruzi invasion involves transsialidase/sialic acid, penetrin/heparan sulfate, and recognition and activation of the TGF signaling pathway.

In this paper we show that, during the acute phase, the CL strain of $T$. cruzi can cause an universal, ubiquitous, or septicemic infection, parasitizing almost all tissues and anatomical structures of mice (Table I), reproducing the findings on human autopsies (Vianna 1911; Chagas 1916a,b; Crowell 1923) and other immunocompromised experimental models $(\mathrm{Ca}-$ labrese et al. 1994; Gonçalves da Costa and Calabrese 1992; Gonçalves da Costa et al. 1986a, 1994).

The detection of parasites in the central veins of adrenal glands (Almeida et al. 1981, 1986) and in the myocardium of chronic chagasic patients (Almeida et al. 1984; Jones et al. 1993) and the recent observation that parasites can be reactivated in HIV patients (Rocha et al. 1994) and form subcutaneous nodules in recipients of cardiac transplants (Bocchi 1987; Stolf et al. 1987) indicate the $T$. cruzi capability to migrate to different organic compartments, changing its location according to the immune state of the host (Gonçalves da Costa et al. 1984). Indeed, in the 13th day of infection, a marked difference between nu/nu and nu/+ mice infected with $T$. cruzi was observed. While in nu/nu mice almost all tissues and organs were intensely parasitized, in nu/+ mice only some organs were parasitized with low intensity (Gonçalves da Costa et al. 1984).

In our material, we present some original anatomical aspects of the $T$. cruzi infection such as parasite involvement of mesenteric membranes, milky spots, intraorbital lachrymal glands, eyes, tracheal and corneal epithelia, anal sebaceous glands, and different genital adnexa (prostate, seminal vesicles, and coagulative, bulbourethral, preputial, and clitoris glands). We also stress the parasite invasion of dermis and adipose tissue and of different epithelial cells (sebaceous glands, mammary excretory ducts, mesothelium, and epididy- 

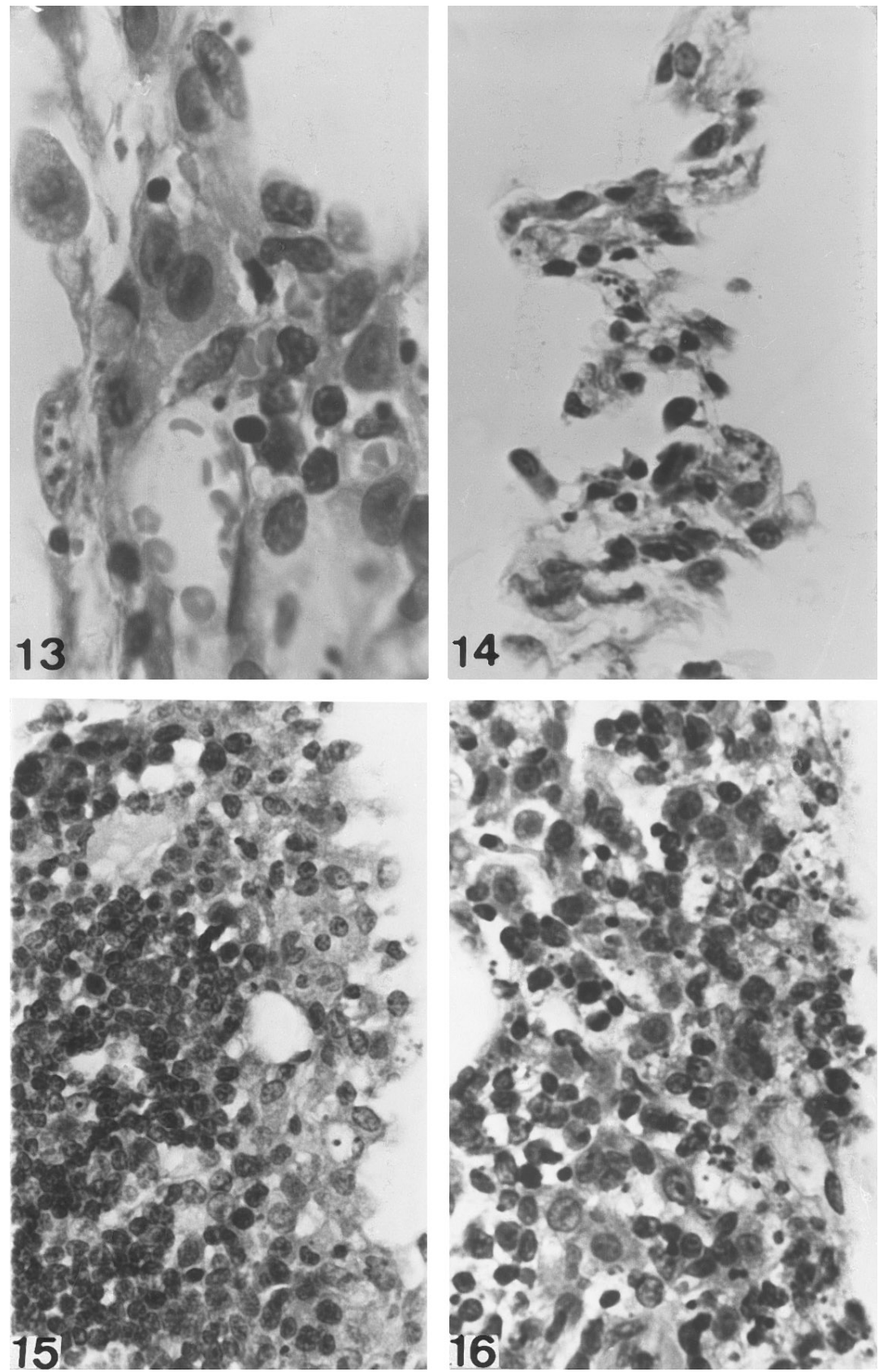

FIG. 13. Mesenteric membrane showing one T. cruzi nest in mesothelial cell. H\&E. $\times 1250$. FIG. 14. Mesenteric membrane with several T. cruzi nests in fibroblasts and/or mesothelial cells. H\&E. $\times 500$. Fig. 15 . Peritoneal milky spot, predominantly of lymphocytic type, covered by parasitized mesothelial cells. H\&E. $\times 500$. FIG. 16. Large number of $T$. cruzi in peritoneal milky spot rich in macrophages. H\&E. $\times 640$. 
mal, tracheal, corneal, urothelial, and mesothelial cells).

Brown and white adipose were two of the most heavily infected tissues in our material, presenting a systemic panniculitis with a large number of parasites (Fig. 3). Mazza et al. (1940) observed very similar lesions in $T$. cruzi-infected $\operatorname{dogs}$ and they referred to the fact that Meyer and Da Rocha Lima (1912) and Da Rocha Lima (1929) considered the adipocytes together with reticuloendothelial and glial cells as the second preference for the $T$. cruzi after heart and skeletal muscle. A tropism for adipose tissue by the Tulahuen strain of $T$. cruzi has also been described (Shoemaker et al. 1970). The occurrence of subcutaneous nodules (lipophagic granulomas) in recipients of cardiac transplants (Bocchi 1987; Stolf et al. 1987) has recently driven attention to the parasitism of adipocytes. According to Andrade and Silva (1995), this situation suggests a link between $T$. cruzi adipocyte parasitism and immunosuppression. In our material, the parasitism was intense in brown and white fats, being more intense in the adipose tissue close to the male and female genital tracts. The fact that adrenal cortex (Vianna 1911; Shoemaker et al. 1970), myelin sheaths in peripheral nerves (this paper, Fig. 2), brain (Chagas 1910; Vianna 1911), ovarian theca interna (Calabrese et al. 1994) and follicular granulosa, dermal and genital sebaceous glands (Fig. 4), and anal glands of the opossum (Lenzi et al. 1984) are sometimes heavily infected reinforces the evidence for the preference of $T$. cruzi for places rich in lipids and steroids. Indeed, adipose tissue has an endocrine function and is active in the conversion of androstenedione to estrone, the major source of estrogen in men and postmenopausal women (Hirsch et al. 1989). Adipose tissue is also rich in stearic acid (Shoemaker et al. 1970), an essential growth factor for $T$. cruzi in vitro (Bone and Parent 1963), and is a source of apolipoprotein $\mathrm{E}$, angiotensin, insulin-like growth factor I, adipsin, and thermogenin which uncouples the oxidation of fatty acids from generation of ATP (Bouillaud et al. 1983; Cunningham et al. 1985; Hirsch et al. 1989). Although a possible function of S-100 protein in T. cruzi growth is unknown, it is interesting to note that both fat cells and Schwann cells contain its B form (S-100-b) (Takahashi et al. 1984; Nakazato et al. 1985), which is a highly acidic calcium binding protein with a molecular weight of 21,000.

Our findings also emphasize the parasite migration to the dermis of the skin, probably in the interior of perivascular macrophages, fibroblasts, and/or small nerve fibers with little monocyte/macrophage reaction or without any inflammation. According to Chagas (1916b) cutaneous processes in humans with acute infections were rarely observed. One of his patients showed dark maculae of rather original appearance, intercalated by small erythematous vesicles full of a serous fluid. Another patient showed gangrenous cutaneous patches which sloughed off and laid bare the subjacent tissues. Mazza et al. (1941) detected parasites only in the skin of hematogenic chagomas and not in morbiliforme schizotrypanide. Medina and Pons (1974) otherwise did not detect parasites in metastatic chagomas and in trypanosomids but only in macrophages in reticular dermis and hypodermis of inoculation chagomas. More or less diffuse erythematous lesions with a great number of diffuse amastigotes in the dermis were observed in nude and newborn BALB/c mice acutely infected with Y and CL strains of T. cruzi. However, when the skin of adult susceptible $\mathrm{C} 3 \mathrm{H} /$ HeN mice was studied, a small colonization of the dermis was seen associated with an intense inflammatory reaction (Gonçalves da Costa and Calabrese 1992). In our adult BALB/c mice we found large numbers of parasites in the dermis with few or no inflammatory infiltrates.

Chagas (1916b) frequently found inflammatory reactions of the eye, such as conjunctivitis, uni- or bilateral keratitis, and occurrence of postkeratitis and secondary panophtalmia among the clinical signs of the human acute form of Chagas' disease. This paper shows, for the first time in the literature, the parasit- 
ism of cornea epithelium, cornea stroma, and retroorbital fibroblasts in a non-inoculation chagoma lesion (Figs. 9-11). We do not know if the parasites were inside nerve processes, which are difficult to detect anywhere in the cornea in standard tissue sections even with the use of special histological techniques.

We found parasites in almost all structures of male and female genitals but in the penile corpora cavernosa. The presence of $T$. cruzi in the genitals was frequently described in humans (Vianna 1911; Chagas 1916a,b) and in immunocompromised mice (Gonçalves da Costa 1986a; Calabrese et al. 1994). Their data and our observation suggest that $T$. cruzi can reach the sperm through the seminipherous tubules, epididymis, and genital adnexa.

Although we detected parasites through all the urinary tract, from the renal pelvis to the urethra, they were completely absent in the renal parenchyma. These results confirm the data of Melo and Brener (1978) which described low renal parasitism by $\mathrm{Y}$, Berenice, and ABC T. cruzi strains and none by CL strain. Although plenty of parasites were observed inside macrophages or/and myoepithelial cells in the pancreas, no parasites were found in acinar cells and islets of Langerhans. The absence or low level of parasitism in very high vascular structures such as in the penile corpora cavernosa, pulmonary and renal parenchyma, islets of Langerhans, hepatic sinusoids, and in atrial endothelium is indicative of some inhibitory properties of tissues rich in endothelial cells and vascular structures. Indeed, parasitism of these structures was only observed in some specific situations. Thus, parasitized cells in the alveolar wall (pneumocyte II ?) and lumen, sometimes associated with the presence of amastigotes in the amniotic epithelium, were only observed in congenital Chagas' disease (Bittencourt et al. 1981). Colonization of Kupffer cells and hepatocytes was described in mice immunossuppressed with cyclophosphamide (Calabrese $e t$ al. 1991). Among different models of immunocompromised mice infected with $\mathrm{Y}$ and $\mathrm{CL}$ strains of $T$. cruzi, athymic mice showed the most consistent colonization of islets of Langerhans (Calabrese et al. 1994). Changes in the $\alpha$ and $\beta$ cells of the islets of Langerhans in infection with the Bolivian strain of T. cruzi were described by Albuquerque et al. (1990) in agreement with Oliveira et al. (1993), who suggested that the lower insulin response in chronic chagasic patients was probably due to denervation of, or injury to, pancreatic $\beta$ cells.

This paper emphasizes the capacity of $T$. cruzi CL strain to invade quite unusual structures such as fat and skin and shows, for the first time in the literature, the parasitism of milky spots, cornea epithelium, cornea stroma, retroorbital fibroblasts, and different male and female adnexa. The infectivity of tissues not described here such as the lymphoid and lymphohematopoietic organs will be the subject of a specific paper (manuscript in preparation). Taken together, our data point to the CL as a paninfective strain of $T$. cruzi, being capable of invading almost all organs and tissues of mice. About 7 decades ago, Crowell (1923) concluded that T. cruzi can infect cells derived from the mesoderm (muscle, fat, suprarenal gland, ovary, uterus, testis, serous membranes, etc.), endoderm (thyroid, thymus, liver, etc.), and ectoderm (brain, ganglion cells, and peripheral nerves). These observations, which could also be applied to our results, raise two very interesting questions: (1) Does T. cruzi use the same mechanism to adhere to and invade so many different types of cells? (2) Why is the parasitism of some highly vascularized organs negative or very low?

\section{ACKNOWLEDGMENTS}

The authors thank Luzia Fátima Gonçalves Caputo, Deise de Andrade Costa, and José Avelino for technical assistance. This paper was supported by grants from Conselho Nacional de Desenvolvimento Científico e Tecnológico $(\mathrm{CNPq})$, Financiadora de Estudos e Projetos (FINEP), Instituto Oswaldo Cruz (FIOCRUZ), Coordenação de Aperfeiçoamento do Pessoal de Ensino Superior (CAPES), Conselho de Ensino para Graduados da UFRJ (CPEGUFRJ), and Fundação de Amparo à Pesquisa do Estado do Rio de Janeiro (FAPERJ). 


\section{REFERENCES}

Albuquerque, A., Ribeiro, R. D., Lopes, R. A., Lamano Carvalho, T. L., And Paula-Lopes, O. V. 1990. Tissue tropism of different Trypanosoma cruzi strains. IX. Alterations in A and B Langerhans islets cells produced by the slender and broad forms of the Bolivian strain. Memórias do Instituto Oswaldo Cruz 85(I), 8.

Almeida, H. O., Teixeira, V. P. A., And Oliveira, A. C. F. 1981. Flebite com parasitismo em supra-renais de chagásicos crônicos. Arquivos Brasileiros de Cardiologia 36(5), 341-344.

Almeida, H. O., Teixeira, V. P. A., Gobbi, H., Rocha, A., AND BRANDÃo, M. C. 1984. Inflamação associada à células musculares cardíacas parasitadas pelo Trypanosoma cruzi em chagásicos crônicos. Arquivos Brasileiros de Cardiologia 42(3), 183-186.

Almeida, H. O., Martins, E., Franciscon, J. U., TeixeIRA, V. P. A., BarbosA, A. J. A., GobBi, H., ANd ReIS, M. A. 1986. Características das células parasitadas pelo Trypanosoma cruzi na parede da veia central das suprarenais de chagásicos crônicos. Revista da Sociedade Brasileira de Medicina Tropical 19, 227-231.

Andrade, S. G., Carvalho, M. L., And Figueira, R. M. 1970. Caracterização morfo-biológica e histopatológica de diferentes cepas de Trypanosoma cruzi. Gazeta Médica da Bahia 70, 32-42.

Andrade, Z. A., ANd Silva, H. R. R. 1995. Parasitism of adipocytes by Trypanosoma cruzi. Memórias do Instituto Oswaldo Cruz 90(4), 521-522.

BiCE, D. E., AND Zeledon, R. 1970. Comparison of infectivity of strains of Trypanosoma cruzi (Chagas 1909). Journal of Parasitology 56, 663-670.

Bittencourt, A. L., Freitas, L. A. R., Araujo, M. O. G., AND JÁcomo, K. 1981. Pneumonitis in congenital Chagas' disease: A study of ten cases. American Journal of Tropical Medicine and Hygiene 30(1), 3842.

BocCHI, E. A. 1987. Imunossupressão na doença de Chagas. Aspectos clínicos-cardiológicos na imunossupressão. Revista da Sociedade Brasileira de Medicina Troprical 20(II), 39-40.

Bone, G. J., And PARent, G. 1963. Stearic acid, an essential growth factor for Trypanosoma cruzi. Journal of General Microbiology 31, 261-266.

Boulllaud, F., Combes-George, M., and Ricquier, D. 1983. Mitochondria of adult human brown adipose tissue contain a 32,000-Mr uncoupling protein. Biosciences Reports 3, 775-780.

BRENER, Z., AND CHIARI, E. 1963. Variaçð̃es morfológicas observadas em diferentes amostras de Trypanosoma cruzi. Revista do Instituto de Medicina Troprical de São Paulo 5, 220-244.

Calabrese, K. S., Bauer, P. G., Lagrange, P. L., And Gonçalves Da Costa, S. C. 1991. Trypanosoma cruzi infection in immunossuppressed mice. Immunology Letters 31, 91-96.
Calabrese, K. S., Lagrange, P. L., and Gonçalves DA Costa, S. C. 1994. Trypanosoma cruzi: Histopathology of endocrine system in immunocompromised mice. International Journal of Experimental Pathology 75, 453-462.

Chagas, C. 1910. Nova entidade morbida do homem. Brazil-Medico 43, 423-428.

Chagas, C. 1916a. Procesos patojenicos da tripanozomiase americana. Memórias do Instituto Oswaldo Cruz $\mathbf{8}$, $5-35$.

Chagas, C. 1916b. Tripanosomiase americana: Forma aguda da moléstia. Memórias do Instituto Oswaldo Cruz 8, 37-60.

Carson, F. L., James, M. S., Martin, J. H., And Lynn, J. A. 1973. Formalin fixation for electron microscopy: A reevaluation. American Journal of Clinical Pathology 59, 365-373.

Crowell, B. C. 1923. The acute form of american trypanosomiasis: Notes on its pathology, with autopsy report and observations on trypanosomiasis cruzi in animals. The American Journal of Tropical Medicine 8(5), 425455.

Cunningham, S., Leslie, P., And Hopwood, D. 1985. The characterization and energetic potential of brown adipose tissue in man. Clinical Science 69, 343-348.

DA Rocha Lima, H. 1929. “Americanische Trypanosomenkrankheit. Anatomia Patológica, tomo V, I Parte del Handbuch der Tropen-Krankheiten de Carl Mense," $3^{\text {rd }}$ ed. Verlag von Johann Ambrosius Barth, Leipzig, Germany.

Deane, M. P., Jansen, A. M., And Lenzi, H. L. 1984. Trypanosoma cruzi: Vertebrate and invertebrate cycles in the same mammal host, the opossum Didelphis marsupialis. Memórias do Instituto Oswaldo Cruz 79, 513 515.

Dvorak, J. A., Engel, J. C., Leapman, R. D., Swyt, C. R., And Pella, P. A. 1988. Trypanosoma cruzi: Elemental composition heterogeneity of cloned stocks. Molecular and Biochemical Parasitology 31, 19-26.

Gonçalves Da Costa, S. C., and Calabrese, K. S. 1992. Schizotrypanids: the occurrence of dermatitis in immunodeficient animals infected with Trypanosoma cruzi. Memórias do Instituto Oswaldo Cruz 87(1), 8185.

Gonçalves Da Costa, S. C., Calabrese, K. S., Alencar, A. A., And Lagrange, P. H. 1986a. Trypanosoma cruzi invasion of structures related to development and central nervous system. Revista Brasileira de Neurologia 22(6), 183-190.

Gonçalves Da Costa, S. C., Calabrese, K. S., and LAgRAnge, P. H. 1994. The colonization of cartilage by Trypanosoma cruzi associated with inflammatory reaction. Revista Brasileira de Reumatologia 34(1), 510.

Gonçalves Da Costa, S. C., Lagrange, P. H., HurTrel, B., Kerr, I., AND Alencar, A. A. 1984. Role of $\mathrm{T}$ lymphocytes in the resistance and immunology of 
experimental Chagas' disease. I. Histopathological studies. Annals d' Immunologie (Institute Pasteur) 135C, 317-332.

Gonçalves Da Costa, S. C., Palhares, P. E. S., CalaBrese, K. S., Alencar, A. A., and Lagrange, P. H. 1986b. Trypanosoma cruzi: Histopathology and time course of infection in indomethacin treated mice. Revista Brasileira de Neurologia 22, 161-164.

Hirsch, J., Fried, S. K., Edens, N. K., AND LeIBEl, R. L. 1989. The fat cell. Obesity. Medical Clinics of North America 73(1), 83-96.

Jones, E. M., Colley, D. G., Tostes, S., Lopes, E. R., VNencAK-Jones, C. L., AND MCCurley, T. L. 1993. Amplification of a Trypanosoma cruzi DNA sequence from inflammatory lesions in human chagasic cardiomyopathy. American Journal of Tropical and Medicine Hygiene 48(3), 348-356.

Lenzi, H. L., Jansen, A. M., And Deane, M. P. 1984. The recent discovery of what might be a primordial escape mechanism for Trypanosoma cruzi. Memórias do Instituto Oswaldo Cruz 79, 13-18.

LenZI, H. L., AND LenZI, J. A. 1986. Swiss-roll technique examination of intestines in experimental animals. Revista da Sociedade Brasileira de Medicina Tropical 19, 106.

Mazza, S., BAsso, G., AND BAsso, R. 1940. Comprobación en adulto, de citoesteatonecrosis subcutánea chagásica por siembra hematógena (Chagomas hematógenos) de $S$. cruzi. Investigaciones sobre Enfermedad de Chagas. Misión de Estudios de Patología Regional Argentina 48, 2-30.

Mazza, S., Basso, G., And BAsso, R. 1941. Comprobación por biopsia de la naturaleza chagásica de la esquizotripanide eritematosa polimorfa. Investigaciones sobre Enfermedad de Chagas. Misión de Estudios de Patología Regional Argentina 56, 2-29.

McDaniel, J. P., ANd DvoraK, J. A. 1993. Identification, isolation, and characterization of naturally occurring Trypanosoma cruzi variants. Molecular and Biochemical Parasitology 57, 213-222.

MedinA, A. O., AND Pons, S. 1974. Manifestaciones cutáneas de la enfermedad de Chagas. Medicina Cutanea Latin America 5, 391-398.

Melo, R. C., AND BRener, Z. 1978. Tissue tropism of different T. cruzi strains. Journal of Parasitology 64, 475-482.

Meyer, M., AND DA Rocha Lima, H. 1912. Zur Entwicklung von S. cruzi in Säugetieren. Archiv fur
Schiffs und Tropische Hygiene, Tomo XVI (Beihelft, 4), 90-94.

Ming, M., Ewen, M. E., And Pereira, M. E. A. 1995. Trypanosome invasion of mammalian cells requires activation of the TGF- $\beta$ signaling pathway. Cell 82, 287296.

Nakazato, Y., Ishida, Y., TAKahashi, K., AND SuZUKI, K. 1985. Immunohistochemical distribution of S-100 protein and glial fibrillary acidic protein in normal and neoplastic salivary glands. Virchows Archiv [Pathologische Anatomie] 405, 299-310.

Oliveira, L. C. M., Juliano, Y., Novo, N. F., AND Neves, M. M. 1993. Blood glucose and insulin response to intravenous glucose by patients with chronic Chagas' disease and alcoholism. Brazilian Journal of Medical and Biological Research 26, 1187-1190.

Rocha, A., Meneses, A. C. O., Silva, A. M., Ferreira, M. S., Nishioka, A., Burgarelli, M. K. N., Almeida, E., Turcato, JR., G., Metze, K., and Lopes, E. R. 1994. Pathology of patients with Chagas' disease and acquired immunodeficiency syndrome. American Journal of Tropical and Medicine Hygiene 50(3), 261-268.

Shoemaker, J. P., Hoffman, J. R., And Hoffman, D. G. 1970. Trypanosoma cruzi: Preference for brown adipose tissue in mice by the Tulahuen strain. Experimental Parasitology 27, 403-407.

Stolf, N. A. G., Higushi, L., Bocchi, E., Bellotti, G., Auler, J. O. C., Uip, D., Amato Neto, V., Pileggi, F., AND JATENE, A. D. 1987. Heart transplantation in patients with Chagas' disease cardomyopathy. Journal of Heart Transplantation 6, 307-312.

Taliaferro, H., AND PizzI, T. 1955. Connective tissue reaction in normal and immunized mice to a reticulotropic strain of Trypanosoma cruzi. Journal of Infectious Disease 96, 199-226.

Takahashi, K., Isobe, T., Ohlusuki, Y., Akagi, T., Sonobe, H., AND OKUYAMA, T. 1984. Immunochemical study on the distribution of alpha and beta subunits of S100 protein in human neoplasms and normal tissues. Virchows Archiv [Cell Pathologie] 45, 385-396.

VianNA, G. 1911. Contribuição para o estudo da anatomia patológica da "Moléstia de Chagas." Memórias do Instituto Oswaldo Cruz 3, 276-294.

Watkins, R. 1966. Comparison of infections produced by two strains of Trypanosoma cruzi in mice. Journal of Parasitology 52, 958-961.

Received 31 January 1996; accepted 22 April 1996 